\title{
The Naturalistic Fallacy Is Modern
}

\author{
By Lorraine Daston*
}

\begin{abstract}
The naturalistic fallacy appears to be ubiquitous and irresistible. The avant-garde and the rearguard, the devout and the secular, the learned elite and the lay public all seem to want to enlist nature on their side, everywhere and always. Yet a closer look at the history of the term "naturalistic fallacy" and its associated arguments suggests that this way of understanding (and criticizing) appeals to nature's authority in human affairs is of relatively modern origin. To apply this category cross-historically masks considerable variability and naturalizes our own assumptions about the natural and the human.
\end{abstract}

\begin{abstract}
T FIRST GLANCE, what we call the naturalistic fallacy seems to be both pervasive and persistent. If what we mean by that term of opprobrium is an appeal to some feature of the natural world in order to represent moral, aesthetic, or social norms, then the historical record (and the daily newspaper) teems with examples, even if we confine ourselves just to the Western tradition since Greco-Roman antiquity. ${ }^{1}$ The stately rounds of the stars modeled the good life for Stoic sages; the rights of man were underwritten by the laws of nature in revolutionary France and in the newborn United States; both sides in recent debates over homosexual marriage and genetically modified organisms routinely invoke nature as their ally. Nature has been invoked to emancipate, as the guarantor of human equality, and to enslave, as the foundation of racism. Nature's authority has been enlisted by reactionaries and by revolutionaries, by the devout and secular alike. In various and dispersed traditions, nature has been upheld as the pattern of all values: the Good, the True, and the Beautiful. ${ }^{2}$

Yet since at least the nineteenth century, powerful voices-John Stuart Mill, Thomas Henry Huxley, Émile Zola-have insisted that there are no values in nature. Nature

* Max Planck Institute for the History of Science, Boltzmanstraße 22, 14195 Berlin, Germany.

${ }^{1}$ This qualification is important: other intellectual traditions forged different conceptual vocabularies. See, e.g., G. E. R. Lloyd, Ancient Worlds, Modern Reflections: Philosophical Perspectives on Greek and Chinese Science and Culture (Oxford: Oxford Univ. Press, 2004), p. 157.

${ }^{2}$ For specific examples (drawn from a vast literature) see William Cronon, ed., Uncommon Ground: Rethinking the Human Place in Nature (New York: Norton, 1996); Philippe Descola and Gísli Pálsson, eds., Nature and Society: Anthropological Perspectives (London: Routledge, 1996); Mikulás Teich, Roy Porter, and Bo Gustafsson, Nature and Society in Historical Context (Cambridge: Cambridge Univ. Press, 1997); Rémi Brague, La sagesse du monde (Paris: Fayard, 1999); Lorraine Daston and Fernando Vidal, eds., The Moral Authority of Nature (Chicago: Univ. Chicago Press, 2004); and the still fundamental Clarence J. Glacken, Traces on the Rhodian Shore: Nature and Culture in Western Thought from Ancient Times to the End of the Eighteenth Century (Berkeley: Univ. California Press, 1967).
\end{abstract}

Isis, 2014, 105:579-587

(C)2014 by The History of Science Society. All rights reserved.

0021-1753/2014/10503-0007\$10.00 
simply is; it takes a human act of imposition or projection to transmute that "is" into an "ought." On this view, there is no legitimate inference that can be drawn from how things happen to be (equated with natural regularities) to how things should be (equated with human norms), from the facts of the natural to the values of the moral order. To try to draw such inferences is to commit what has come to be called the "naturalistic fallacy"-a kind of covert smuggling operation in which cultural values are transferred to nature and nature's authority is then called upon to buttress those very same values. This sort of value trafficking can be politically consequential, as when medieval rulers defended the subordination of the bulk of the population to the aristocracy and clergy on the grounds that it was natural for the hands and feet to serve the head and heart of the "body politic," or when late nineteenth-century opponents of higher education for women argued that the natural vocation of all women was to be wives and mothers. ${ }^{3}$ Subordination and domesticity were thereby "naturalized": contingent (and controversial) social arrangements were shored up by the necessity or desirability of allegedly natural arrangements. With similar examples in mind, Mill condemned such arguments as not just logically false but morally pernicious to boot: "Either it is right that we should kill because nature kills; torture because nature tortures; ruin and devastate because nature does the like; or we ought not to consider at all what nature does, but do what it is good to do." 4 Yet however pernicious, the naturalistic fallacy seems to be ubiquitous - and, furthermore, oddly plastic.

It is just this plasticity that ought to give both historians and philosophers pause. Historians, because they understand the power of context: what kind of argumentative strategy adapts itself so flexibly to such diverse times and places, especially when the very meaning of the natural mutates across cultures and historical epochs? ${ }^{5}$ Philosophers, because committing a fallacy signals at least the intention to convince by reasoned argument: can reasons that potentially support all sides of almost any debate be called an argumentative strategy at all? Natural history is, for example, a treasure trove of examples that can be and have been cited for any and all positions: the monogamy of albatrosses versus the polygamy of red-winged blackbirds; the hierarchical chimpanzees versus the egalitarian bonobos. That the natural and the moral have been entangled for a very long time is beyond dispute. But when, why, and how exactly did that entanglement become the "naturalistic fallacy"? What is the history of our own category of analysis?

The phrase "naturalistic fallacy" was coined in 1903 by the Cambridge philosopher George Edward Moore in a context quite remote from current usage. In an effort to block attempts to define the ethical good by appeal to any more fundamental category (e.g., pleasure or social harmony), the intuitionist Moore stipulated that "the naturalistic fallacy

\footnotetext{
${ }^{3}$ On "body politic" see Jacques Krynen, "Naturel: Essai sur l'argument de la nature dans la pensée politique française à la fin du moyen age," Journal des Savants, Apr.-June 1982, pp. 169-190, on p. 175; on higher education for women see Arthur Kirchhof, ed., Die akademische Frau: Gutachten hervorragende Universitätsprofessoren, Frauenlehrer und Schriftsteller über die Befähigung der Frau zum wissenschaftlichen Studium und Berufe (Berlin: H. Steinitz, 1897).

${ }^{4}$ John Stuart Mill, "Nature," in Three Essays on Religion (1874), in Mill, Essays on Ethics, Religion, and Society, ed. J. M. Robson (London: Routledge, 1996), pp. 373-402, on p. 386.

${ }^{5}$ Again the literature is vast, but see, in addition to the references given in note 2, above, R. G. Collingwood, The Idea of Nature (New York: Oxford Univ. Press, 1945); Arthur O. Lovejoy, "Nature' as Aesthetic Norm," in Essays in the History of Ideas (Baltimore: Johns Hopkins Univ. Press, 1948), pp. 69-77; Jean Ehrard, L'idée de la nature en France dans la première moitié du XVIIIe siècle (1963; Paris: Michel, 1994); "Nature," in Raymond Williams, Keywords: A Vocabulary of Culture and Society, 2nd ed. (1976; New York: Oxford Univ. Press, 1983), pp. 219-224; John Torrance, ed., The Concept of Nature (Oxford: Clarendon, 1992); and Harald Patzer, "Physis: Grundlegung zu einer Geschichte," Sitzungsberichte der Wissenschaftlichen Gesellschaft an der Johann Wolfgang Goethe-Universität Frankfurt-am-Main, 1993, 30:217-280.
} 
[is] the fallacy which consists in identifying the simple notion which we mean by 'good' with some other notion." ${ }^{\prime \prime}$ Note that Moore's prohibition is both sweeping, ruling out any further definition of the good, whether or not derived from nature; and an unusual kind of fallacy, since it does not involve drawing false inferences but, rather, holding (according to Moore and his fellow ethical intuitionists) false views.

The wobbly claim to the status of fallacy must have made other philosophers uncomfortable, since by the 1930s Moore's alleged naturalistic fallacy had come to be regularly conflated with a more standard sort of unwarranted inference, from "is" propositions to “ought" prescriptions - usually traced back to David Hume's argument blocking inferences from factual to moral judgments. The former were made by the faculty of reason and pertained to "the real relation of ideas, or to the real existence of matters of fact"; the latter by the passions, which perceive matters of fact as virtues and vices, which "may be compar'd to sounds, colours, heat and cold" and other secondary qualities in the mind rather than its objects. Although he did not use the word "fallacy," Hume condemned such inferences as logical errors and indicted almost all moral systems for committing them. There is no indication that Hume thought matters of fact were exclusively natural, and he offered a nuanced discussion as to how virtues and vices may be deemed natural or unnatural, depending on how those terms are defined. ${ }^{7}$

How then did Hume's argument come to be identified with Moore's alleged fallacyespecially since by Moore's lights Hume himself was guilty of the naturalistic fallacy in deriving moral judgments from the passions? This is a genuine puzzle. A 1939 article by the University of Michigan philosopher William A. Frankena (who had studied with Moore at Cambridge) that valiantly attempted to sort out the conceptual mess provides valuable clues. Noting what strange bedfellows Hume and Moore made, Frankena pointed out that all they really seemed to share was a "bifurcationist" ontology of ethical judgments: just as Hume bifurcated "is" and "ought" propositions, intuitionists like Moore asserted that "ethical characteristics are different in kind from non-ethical ones." There the analogy ended, and Frankena expressed strong doubts as to whether Moore's so-called naturalistic fallacy had anything to do with either nature or fallacies. At least among philosophers, Frankena's efforts to disperse the fog surrounding the naturalistic fallacy seem to have been futile, despite occasional protests from within the ranks. Nearly fifty years later, Bernard Williams still felt obliged to remark regarding "the naturalistic fallacy" that "it is hard to think of any other widely used phrase in the history of philosophy that is such a spectacular misnomer."

${ }^{6}$ G. E. Moore, Principia Ethica (1903), ed. Thomas Baldwin (Cambridge: Cambridge Univ. Press, 1993), pp. 61-62.

${ }^{7}$ Indeed, in other contexts, Hume argued forcefully for not making any principled distinction between natural and moral matters of fact: "And indeed, when we consider how aptly natural and moral evidence link together, and form only one chain of argument, we shall make no scruple to allow, that they are of the same nature, and derived from the same principles." David Hume, "Of Liberty and Necessity," in An Enquiry Concerning Human Understanding (1748), ed. Eric Steinberg (Indianapolis: Hackett, 1977), p. 60. On vices and virtues see Hume, A Treatise on Human Nature (1739-1740), ed. L. A. Selby-Bigge, 2nd ed., with revisions by P. H. Nidditch (Oxford: Clarendon, 1978), Bk. 3, Pt. 1, sects. 1-2, pp. 456-475, on pp. 458, 469. The tradition of insisting that virtues and vices were neither natural nor unnatural dates back to Aristotle's Nicomachean Ethics 2.1.

${ }^{8}$ William A. Frankena, "The Naturalistic Fallacy," Mind, 1939, N.S., 48:464-477, on p. 467; and Bernard Williams, Ethics and the Limits of Philosophy (1985; New York: Routledge, 2006), p. 121. Williams largely seconded Frankena's bifurcationist diagnosis of the confusion, although he widened the categories "ethical" and "nonethical" to " "evaluative' terms" and a "nonevaluative class" that "contained a wide variety of items, such as statements of fact, mathematical truths, and indeed such things as statements about God" (p. 122). In this fashion, not only the is/ought but also the fact/value distinction could be absorbed into the naturalistic fallacy. 
Historians may well respond impatiently. What does it matter if the phrase "naturalistic fallacy" has a dubious philosophical lineage and doesn't meet that discipline's strict criteria for fallacies? Surely it is still a mistake to enlist nature in patently human battles (whether over the ethics of slavery or the aesthetics of nonfigurative art) — and a frequently dangerous mistake at that. What does it matter, they will press on, what we call the mistakes, so long as we are vigilant in identifying and criticizing them wherever they appear? Historians of science, acutely aware of the immense damage wrought by naturalized categories of race, gender, intelligence, and normalcy in the modern human and life sciences, will be especially vehement on this point. The naturalistic fallacy by any other name would smell as foul.

The reason for nonetheless attending to the crooked trajectory of the naturalistic fallacy is that it may accomplish two eminently historical goals: first, it will be a first step toward historicizing our own categories of analysis; and second, once historicized, these categories may well change both our diagnosis of and therapy for illegitimate invocations of nature's authority. We may even begin to understand how and why nature comes to have authority over human affairs at all. To sharpen the point: the sources of the philosophical confusion over the naturalistic fallacy are specific to a historically particular understanding of nature that emerges in the late eighteenth century. Moreover, this modern notion of nature is a precondition for what many critics take to be the most egregious instances of the naturalistic fallacy.

Once the historicity of what we have come to call the naturalistic fallacy is recognized, several apparent riddles solve themselves. Not only can we make sense of philosophical conflations of Moore's naturalistic fallacy with Hume's is/ought opposition (sometimes with the Vienna Circle's fact/value distinction thrown in for good measure); we may also query whether the naturalistic fallacy is really so strangely persistent after all. There are as many ways of thinking with nature as there are ways of thinking about nature, as the mind-boggling variety of concepts, metaphors, artworks, and arguments across cultures and epochs testifies - and as the other essays in this Focus section bear ample witness. But few of these share the presuppositions that frame our own uneasiness about the false packaging of the human in natural wrapping. Nature we always have with us, but not the naturalistic fallacy.

Like all truly interesting words, "nature" is a mille-feuille of meanings. It can refer to everything in the universe (sometimes including and sometimes excluding human beings), to what is inborn rather than cultivated, to the wild rather than the civilized, to raw materials as opposed to refined products, to the spontaneous as opposed to the sophisticated, to what is native rather than foreign, to the material world without divinity, to a fruitful goddess, and to a great deal else, depending on epoch and context. Ancient meanings still resonate in modern European vernaculars: for example, the sense of specific nature, so prominent in Aristotle, as that which defines the essence of a kind of thing, be it copper or foxes; or the sense, strong in some Hippocratic writings, of local nature as the characteristic configuration of flora, fauna, climate, topography, and waters that gives a particular place its specificity. ${ }^{9}$ But the accretion of new layers did not stop in antiquity;

\footnotetext{
${ }^{9}$ See Patzer, "Physis" (cit. n. 5); Felix Heinimann, Nomos und Physis: Herkunft und Bedeutung einer Antithese im griechischen Denken des 5. Jahrhunderts (1945; Darmstadt: Wissenschaftliche Buchgesellschaft,

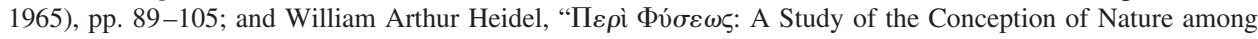
the Pre-Socratics," Proceedings of the American Academy of Arts and Sciences, 1910, 45:79-133, esp. pp. 97-99.
} 
for our purposes, the significant novelty occurs in the late eighteenth and early nineteenth centuries, when the understanding of nature as governed by universal natural laws reverses its political charge, from reformist and even revolutionary to conservative.

A complex interplay of natural philosophy, ethics, epistemology, metaphysics, theology, political theory, and jurisprudence in the seventeenth and eighteenth centuries imbued the metaphor of natural law with strong legislative and voluntarist overtones: both the law of gravitation (an example of a lex naturalis) and the law of nations (an example of jus naturae) could be construed as divine edicts. ${ }^{10}$ In contrast to specific natures (occasionally transgressed by monsters) and local natures (by definition geographically circumscribed), these edicts in principle enjoyed universal and unexceptionable jurisdiction. Practice was another matter, at least for the natural laws of the jurists, which notoriously fell short of the universality and uniformity of the natural laws of celestial mechanics. It was in this spirit that Charles Secondat de Montesquieu bemoaned the disparity between the laws of the natural and moral realms in De l'esprit des lois (1748): "But the intelligent world cannot be so well governed as the physical world. For even though the former also has its laws, it does not follow them as constantly as the physical world follows its [laws]. . . . Man, as a physical being, is, just like other bodies, governed by invariable laws; as an intelligent being, he violates incessantly the laws established by God, and changes those that he has established himself." When M. J. A. N. Condorcet and other Enlightenment philosophes criticized Montesquieu, it was not because they rejected his neo-Hippocratic theory of the interrelations of climates and characters, but because in their view any moral standard not as universal and uniform as natural law risked anything-goes relativism. ${ }^{11}$

For the many Enlightenment thinkers who, like Condorcet, invoked the authority of universal natural law in the human realm, nature was an aspiration rather than an inexorable reality. Allegedly natural laws provided an Archimedean point from which critics could issue severe verdicts on reigning social and political conventions. It was precisely the divergence between universal natural law and human realities that made nature into a weapon wielded primarily by reformers and revolutionaries, whether in theology or political theory. In his highly influential Analogy of Religion, Natural and Revealed (1736), the Anglican bishop Joseph Butler recommended that rational Christians concentrate on "the Conduct of Nature with respect to intelligent Creatures; which may be resolved into General Laws or Rules of Administration, in the same way as many of the Laws of Nature respecting inanimate Matter may be collected from Experiments," in the hopes of discovering a uniform doctrine amidst the Babel of sects. Some fifty years later, the Declaration des droits de l'homme et du citoyen promulgated at the outset of the French Revolution in 1789 attributed all "public ills and corruption of governments" to the ignorance or neglect of "the natural, sacred, and inalienable rights of man."12 (See Figure 1.)

\footnotetext{
${ }^{10}$ For an interdisciplinary survey of these complex developments see Lorraine Daston and Michael Stolleis, eds., Natural Laws and Laws of Nature in Early Modern Europe (Farnham, Surrey: Ashgate, 2008), and the bibliography contained therein. On ancient formulations see Daryn Lehoux, "Laws of Nature and Natural Laws," Studies in the History and Philosophy of Science, 2006, 37:527-549.

${ }^{11}$ Charles de Secondat de Montesquieu, Esprit des lois [1748], avec les notes de l'auteur et un choix des observations (Paris: Firmin-Didot Frères, 1845), p. 5 (my translation); and M. J. A. N. Condorcet, "Commentaire sur le vingt-neuvième livre de l'Esprit des lois," in Antoine-Louis Destutt de Tracy, Commentaire sur l'Esprit des lois de Montesquieu (Paris: Dalibon, 1828), pp. 380-381.

${ }^{12}$ Joseph Butler, Analogy of Religion, Natural and Revealed (London: James, John and Paul Knapton, 1736), p. viii; and Claude-Albert Colliard, ed., La Déclaration des droits de l'homme et du citoyen de 1789, ses origins, sa pérennité (Paris: Documentation Française, 1990).
} 


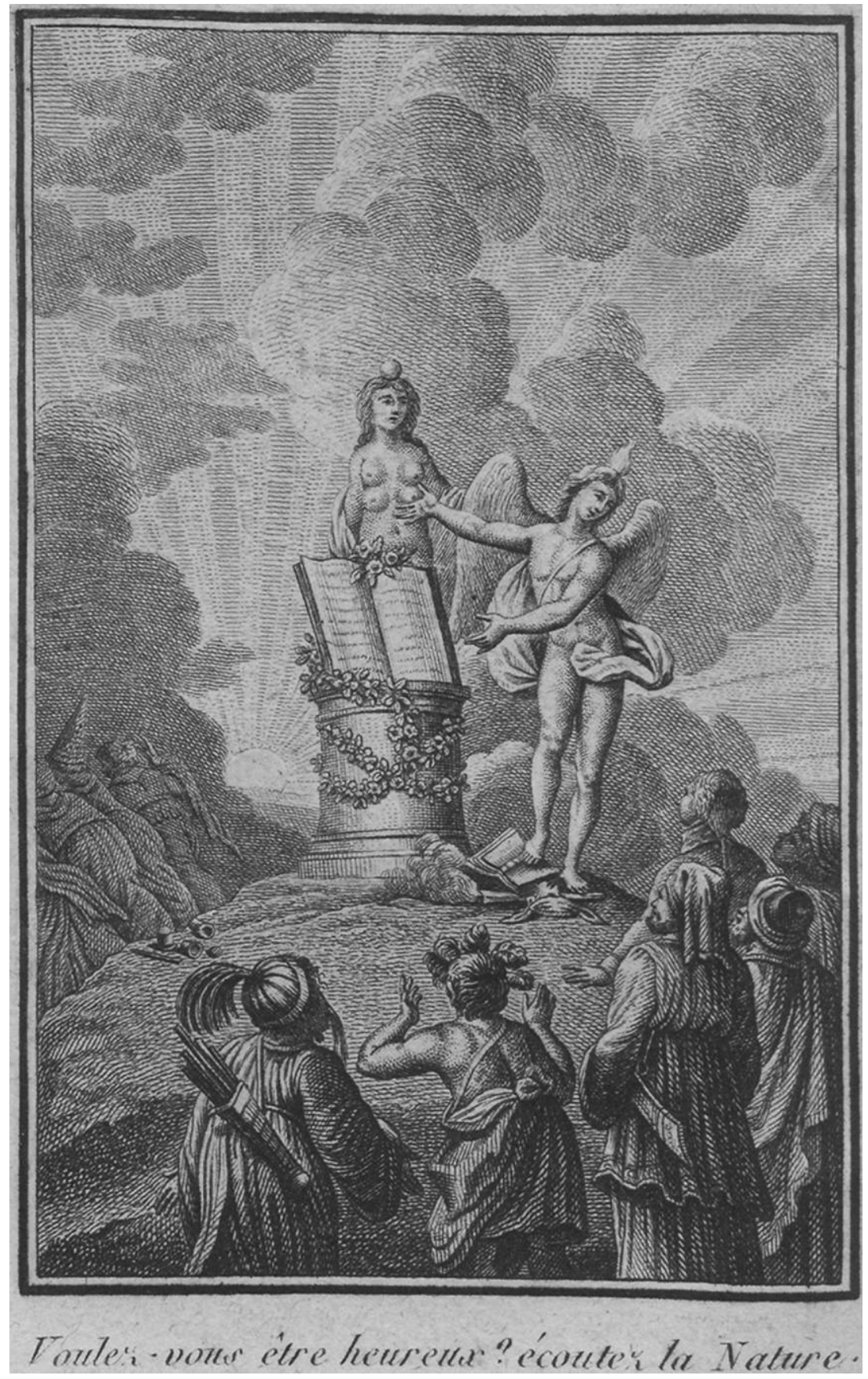

Figure 1. "Voulez-vous être heureux? Écoutez la nature." Platon Blanchard, Catéchisme de la nature; ou, Religion et morale naturelles (Paris: Chez Maradan, An II [1794]), frontispiece. With the kind permission of the Cambridge University Library. 
These were calls to arms, not affirmations of matters of fact. Enlightenment nature was saturated with normative authority, but more as utopian project than as hard reality.

By the mid-nineteenth century nature had changed sides and joined the conservatives, as liberals like Mill well recognized. Nature's authority shifted from the hopeful future tense of the progressive reformers to the grim-faced present tense of their opponents: things are as they must be; efforts at improvement are at best futile and at worst downright harmful. Thomas Malthus helped to set the tone in his critique of the perfectibility doctrines advanced by Condorcet and William Godwin:

It has appeared that a society constituted according to Mr. Godwin's system must, from the inevitable laws of our nature, degenerate into a class of proprietors and a class of labourers, and that the substitution of benevolence for self-love as the moving principle of society, instead of producing the happy effects that might be expected from so fair a name, would cause the same pressure of want to be felt by the whole of society, which is now felt only by a part. ${ }^{13}$

Nature in the Enlightenment had been quite openly saturated with values, but its authority over human affairs was exercised through rational assent rather than physical necessity. Nature during much of the nineteenth and twentieth centuries had been purged of values because it ruled entirely by physical necessity. ${ }^{14}$ As the Russian novelist Ivan Turgenev put it: "she [nature] knows nothing of art or liberty, as she does not know the good."15 Within a will-centered, Kantian ethics, nature does not qualify for moral agency, much less moral authority: nature neither deliberates nor dictates; the natural and the moral belong to different ontological categories.

There is nothing new about the link between nature and necessity, nor with the exculpatory inferences drawn from such links: conduct ascribed even to specific natures rather than to natural laws had been exempted in whole or in part from praise or blame. ${ }^{16}$ As Brooke Holmes shows in her article for this Focus section, the Stoics and other ancient ethical schools were preoccupied with the problem of making space for agency amidst the necessities imposed by animal and human natures. Nor was there any novelty in binary oppositions between nature and — depending on place and period-art, education, refinement, civilization, nurture, or culture. What was new was, first, the moral evacuation of nature as a whole and, second, the sharpness of the line that divided nature from its human complements. What had for millennia been conceived as a collaboration between nature and, for example, custom, especially in the realm of individual human character and

${ }^{13}$ William Godwin, Enquiry Concerning Political Justice and Its Influence on Morals and Happiness (1793); M. J. A. N. Condorcet, Esquisse d'un tableau historique des progress de l'esprit humain (1795); and Thomas Malthus, First Essay on Population (1798), with a foreword by Kenneth E. Boulding (Ann Arbor: Univ. Michigan Press, 1959), Ch. 15, p. 100.

${ }^{14}$ Several historians have remarked on this shift: see, e.g., A. E. Pilkington, “'Nature' as Ethical Norm in the Enlightenment," in Languages of Nature: Critical Essays on Science and Literature, ed. Ludmilla Jordanova (London: Free Association, 1986), pp. 51-85, esp. p. 55. For a detailed example of the impact of this shift see Lorraine Daston, "The Naturalized Female Intellect," Science in Context, 1992, 5:209-235.

${ }^{15}$ Ivan Turgenev, Dovolno [Enough] (1864), quoted in Isaiah Berlin, "Fathers and Children" (1970), in Turgenev, Fathers and Sons (1861), trans. Rosemary Edmonds (Harmondsworth: Penguin, 1975), p. 57.

${ }^{16}$ Even behavior considered abhorrent, such as sodomy in medieval Christian contexts, was condemned less severely if attributed to the malefactor's nature; see the nuanced discussion of scholastic arguments in Joan Cadden, Nothing Natural Is Shameful: Sodomy and Science in Late Medieval Europe (Philadelphia: Univ. Pennsylvania Press, 2013), esp. pp. 69-72. It is interesting to note that recent papal encyclicals on homosexuality have also tempered condemnations in light of similar arguments from specific natures ("impulsa innati genus"): Congregatio pro Doctrina Fidei, "Declaratio de quibusdam quaestionibus ad sexualem ethicam spectantibus," Acta Apostolicae Sedis, 31 Jan. 1976, 68(1):77-96, on p. 84. 
abilities, was reimagined as competition. Within the older model, first and second nature collaborated: in pedagogy, inborn dispositions and education worked together to form conduct; in medicine, inborn dispositions could be strengthened or weakened by regimen. In a metaphor typical of this tradition, Francis Bacon linked the cultivation of soul and garden: "A Mans Nature runnes either to Herbes, or Weeds; Therefore let him seasonably Water the One, and Destroy the Other." ${ }^{17}$ Within the newer model, nature and nurture were independent dimensions to be pulled apart and compared. Francis Galton not only coined this "convenient jingle of words" in his prosopographical study English Men of Science: Their Nature and Their Nurture (1874); his analyses of "the competition between nature and nurture" (usually awarding the palm to nature) set the mold for still-ongoing research programs in psychology, linguistics, biology, medicine, and anthropology that seek to separate and measure the relative contributions of each component rather than to study their interaction. ${ }^{18}$

It is only within this modern framework that we can make sense of the naturalistic fallacy, both its confusions and its tenacity. The naturalistic fallacy and its barnacle-like accretions assume what Frankena called a "bifurcationist ontology" that prohibits commerce between the two immiscible realms. Repeated efforts on the part of monists of both materialist and idealist persuasion to dissolve the dichotomy in favor of one or another realm have only reinforced its binary logic. Because distinctions between "is" versus "ought" or between facts versus values parallel this structure of immiscible binaries, they are all too easily conflated with one another, even if the analogies do not stand up to close scrutiny (e.g., matters of fact that have nothing to do with nature). The key shared feature of all these versions of the naturalistic fallacy has less to do with nature than with a militantly policed border between whatever two realms are put asunder. It is the little word "versus" that shoulders the burden of belief.

Despite bans on border crossing, the nature pole exerts a powerful magnetism on defenders of the status quo, as their more liberal adversaries from John Stuart Mill and Karl Marx to the latest critics of research on innate gender or racial differences have been swift to point out. By assigning current conditions - the underrepresentation of women in mathematics, say, or the overrepresentation of African-American men in U.S. prisons-to the realm of nature, conservatives could immobilize reform movements by asserting the impossibility of their success. ${ }^{19}$ As Erika Milam relates in her article for this Focus section,

\footnotetext{
${ }^{17}$ Francis Bacon, "Of Nature in Men," in The Essayes or Counsels, Civill and Morall (1625), ed. Michael Kiernan (Oxford Francis Bacon, 15) (Oxford: Clarendon, 2000), p. 120. The extended sense of "culture" in the modern sense stems from the Ciceronian idea of the cultivation of the soul, from the primary sense of "the tending of natural growth" (as in "agriculture"): "Culture," in Williams, Keywords (cit. n. 5), pp. 87-91, on p. 87 .

${ }^{18}$ Francis Galton, English Men of Science: Their Nature and Their Nurture (1874), ed. Ruth Schwartz Cowan (London: Cass, 1970), pp. 12, 16. Galton wrote his book as a reply to the botanist Alphonse de Candolle's Histoire des sciences et des savants depuis deux siècles (1872), which in turn was a critique of Galton's Hereditary Genius (1869). For a review of recent research in the human sciences see G. E. R. Lloyd, Cognitive Variations: Reflections on the Unity and Diversity of the Human Mind (Oxford: Oxford Univ. Press, 2007), surveying recent literature in linguistics and anthropology, and Evelyn Fox Keller, The Mirage of a Space between Nature and Nurture (Durham, N.C.: Duke Univ. Press, 2010), surveying the latest developments in biology; both point out how resistant the nature-versus-nurture framework has proven to countervailing evidence.

${ }^{19}$ The exceptions prove the rule: when liberal reform movements like that for gay liberation invoke the obduracy of nature-in this case, the impossibility of changing an allegedly inborn same-sex orientation-they do so in order to disarm exhortations that gay people mend their ways: in addition to the references cited in note 16, above, see Hanspeter Heinz, "Zu gesetzlichen Regelungen gleichgeschlechtlicher Lebensgemeinschaften, Forschungsbericht über die Haltung der Katholischen Kirche," in Die Rechtstellung gleichgeschlechtlicher
} 
this is why the biologist Robert Trivers and the Black Panther activist Huey Newton, who both considered themselves men of the Left, worried about how their political comradesin-arms would respond to the claim that the self-deception responsible for "artificially preserving social injustice in the United States" had evolutionary roots. The strictest and strongest version of this argument from nature need not appeal to values at all; on the contrary, just as Malthus tinged his refutation of Condorcet and Godwin with regret-if only their roseate visions of a better humanity were compatible with the nature of things-so opponents of reform need not query the desirability, only the possibility, of ever changing the way things are now. ${ }^{20}$ The very existence of the bifurcationist ontology is a constant, if lopsided, temptation to trafficking across the electrified border.

As both Matthew Stanley and Warwick Anderson argue in their essays for this Focus section, traffic flows in both directions: astronomers gesture toward the stars in support of international governance, while cosmologists use the anthropic principle to "fine-tune" their theories; immunologists look to social theory and philosophy to understand the boundaries of the self-and vice versa. In contrast to premodern ontologies-whether in the Hellenistic period or the Enlightenment—in which nature could be (in Holmes's words) "synonymous with virtue," the yin/yang logic of the natural versus the human (often conflated but not identical with the natural versus the moral) renders analogies in any direction illicit. Against this background, such analogies can only be understood as metaphorical or as reductionist. When it is human nature that is at stake, the situation is particularly murky. By driving a wedge between "human" and "nature," the bifurcationist ontology renders the term "human nature" oxymoronic. ${ }^{21}$

If the naturalistic fallacy is peculiarly-and "peculiar" is the mot juste here-modern, then what about the abundant connections - analogies, explanations, justifications, metaphors, representations of all kinds, from model to microcosm-made between nature and human affairs in other epochs? There is every reason to expect that they will be just as specific to their time and place, depending on the dominant conception of nature, the terms to which it is routinely opposed, and the work to be done by the connection. This last point is perhaps the most important. By allowing the modern naturalistic fallacy to swallow up all invocations of nature, everywhere and always, we have obscured not only the history of that polymorphous notion, nature, but also that of the equally distinct forms of authority it has exercised.

Lebensgemeinschaften, ed. Jürgen Basedow, Klaus Hopt, Hen Kötz, and Peter Dopffel (Tübingen: Mohr Siebeck, 2000), pp. 277-308, esp. p. 293.

${ }^{20}$ The weaker version of the argument, which does at least implicitly attribute values to nature, usually draws organic analogies-e.g., between human and ant slavery - and thereby founders on the sheer variability of natural history: every justification by appeal to the example of one species can be refuted by the counterexample of other species, equally natural. For obvious reasons, primatology is a particularly rich vein for such warring analogies aiming to justify this or that aspect of human behavior, though bees and ducks have also had their innings.

${ }^{21}$ Thoughtful social theorists have long recognized this impasse, without being able to find a way out; see, e.g., Clifford Geertz, "The Impact of the Concept of Culture on the Concept of Man," in New Views of the Nature of Man, ed. John Platt (Chicago: Univ. Chicago Press, 1965), pp. 93-118. 